\title{
Cold Climate Fire Risk; A Case Study of the Lærdalsoyri Fire, January 2014
}

\author{
Torgrim Log* (D), Stord/Haugesund University College, 5528 Haugesund, \\ Norway
}

Received: 20 February 2015/Accepted: 28 August 2015

\begin{abstract}
Parameters leading to the severity of the fire in Lærdalsøyri, Norway, January 18th to 19th 2014, have been analyzed. The fire in the first villa developed significantly faster than the fire fighters could handle and the fire quickly spread to other structures. In addition to 36 modern buildings, 4 historic buildings in Gamle Lærdalsøyri cultural heritage area were lost. Heroic effort of local and neighbor community fire brigades, police, military forces and volunteers prevented the fire from destroying the whole village, including the remaining 157 historic buildings. Adiabatically heated (low humidity) air from surrounding high mountains gave outdoor wood fuel moisture content (FMC) of about $7.6 \%$. Inside inhabited buildings, it is shown that the wooden products reached about $4.5 \%$ FMC prior to the blaze. When ignited, this resulted in rapid fire development. Two story villas burned down in less than $1 \mathrm{~h}$ while producing much embers and firebrands. Strong shifting winds subsequently spread the fire to neighbor houses by flame contact (periodically $20 \mathrm{~m}$ long horizontal flames) and over long distances $(200 \mathrm{~m})$ by embers and firebrands. Based on the present work, an increased fire risk associated with low FMC in inhabited wooden houses during winter time can be predicted. This is of value when considering measures to reduce the probability of a fire outbreak as well as measures mitigating the escalation of a potential fire.
\end{abstract}

Keywords: Winter fire risk, Adiabatic heating, Low humidity, Wind, Blaze

\section{Introduction}

Norway has a rich tradition with respect to wooden constructions. The most wellknown of these are the 28 remaining Viking Stave Churches as well as Viking ships preserved in sea mud or at burial sites. Due to the humid climate in major parts of the country most wooden constructions have, however, disappeared during the centuries in natural wood deterioration processes. Several wooden structures were also lost in fires.

There are still 180 sites with quite well preserved wooden houses from the years 1700 to 1900 . Two of these sites are on the UNESCO World Heritage List, i.e. Bryggen harbor area (Bergen) and the Røros mountain village. The best way to protect the majority of the historic building sites is usually to allow the structures

\footnotetext{
* Correspondence should be addressed to: Torgrim Log, E-mail: torgrim.log@hsh.no
} 
to remain a part of the daily village or city life. This will, of course, expose them to the fire risks of the modern society.

December is the month with the highest fire frequency, partly due to candle lights in the Advent period, Christmas and New Year celebration. The use of wood stoves and excessive electricity consumption in the cold and windy winter months also contribute to this increased fire frequency.

During the winter season major conflagrations like the one in Alesund, Norway, on January 23rd 1904 may occur. The cause of the Alesund fire is unknown. Winds of storm strength $(22 \mathrm{~m} / \mathrm{s}$ to $30 \mathrm{~m} / \mathrm{s})$ was, however, a major reason for the fire brigades not being able to control or extinguish the fire. The wind direction changed during the fire compounding the already challenging situation. That fire was one of the most severe fires in Norway's modern history, killing one person, destroying 850 structures and resulting in 10.000 to 12.000 homeless people.

The last time a fire really shocked the nation was when devil worshipers burned down the 850 years old Fantoft Stave church outside Bergen June 6th 1992. In a 3 year period about 40 churches, several of them historic buildings, were set on fire. This dark period of cultural heritage vandalism and attack on the Norwegian pride resulted in a major focus on fire protection of historic buildings. In the legislation following, i.e. St.meld. nr. 41 (2000 to 2001) "Brann- og eksplosjonsvern" (Parliament white paper 41 (2000 to 2001) "Fire and Explosion Protection") it was stated that loss of major heritage value and major town fires shall be prevented. But then, 13 years later, Lærdalsøyri was struck by fire. Saturday night, January 18th 2014, a private villa in the street Kyrkjeteigen, $80 \mathrm{~m}$ from the fire station, caught fire. 40 buildings, including 4 historic buildings in Gamle Lærdalsøyri cultural heritage site, were lost in the fire, which was the largest fire in Norway since World War II. With all the knowledge and experience from previous fires, how could it be possible that the community of Lærdal experienced a fire destroying so many buildings and threatening the whole Lærdalsøyri historical site?

The motivation for studying this fire is a potential learning outcome that may help predicting high fire risk periods and preventing future major fires in areas of wooden structures in cold climates. The objectives are to analyze the dynamics of the Lærdalsøyri fire and identify physical parameters that may explain the severe fire development. When identified, the potential for predicting similar risks in the future will be discussed and recommended mitigating measures presented. As the fire spread mechanism is already described by Steen-Hansen et al. [1], the focus will be on the fire risk and fire development within inhabited houses. The methods include interviews of personnel on scene, collecting meteorological observations before the fire and inductive reasoning based on this as well as deductive reasoning based on water vapor pressures, atmospheric lapse rate, diffusion theory and general fire dynamics.

\section{Laerdal and Laerdalsoyri}

Lærdal is a $1340 \mathrm{~km}^{2}$ fjord, valley and mountain community of 2200 inhabitants in Western Norway, see Figure 1. The Lærdalsøyri village $\left(61.1^{\circ} \mathrm{N}, 7.5^{\circ} \mathrm{E}\right)$ with 1150 inhabitants is the administration centre. The main tourist attractions in Lær- 
dal include the Borgund Stave Church (from 1182), the historic roads through the area and Gamle Lærdalsøyri. The 161 historic buildings (from 1700 to 1800) in Gamle Lærdalsøyri, represented one of the best preserved original old wooden house communities in Norway, see Figure 2.

To be located in the Western Norway, the climate in Lærdal is very dry, with annual precipitation just short of $500 \mathrm{~mm}$. The December and January average precipitation is $49 \mathrm{~mm}$ and $37 \mathrm{~mm}$, respectively. This dry climate has been a blessing for preservation of the old wooden constructions. Due to the historic value of numerous buildings in Lærdal, as well as the economic value of the tourism, emphasis has been placed on fire safety with support from the Norwegian Directorate of Cultural Heritage (Figures 3, 4).

\section{The Fire Scenario}

\subsection{Saturday Night, January 18th}

22.54: The owner of a private villa (Kyrkjeteigen 8) called the fire brigades to report a fire in the neighbor villa (Kyrkjeteigen 6). 22.54: 13 fire fighters and one fire officer sign up for duty, leave their homes aiming for the unmanned fire station. The police forces were informed about the fire. 22.59: The first fire truck arrived at the fire scene. 23.02: The police officer in charge was informed about fire spread to a neighbor villa. 23.15: Three villas were involved in the fire. 23.20: The first police officers arrived at the scene and reported "fire in 3 villas and ember all over Lærdalsøyri". 23.48: The police forces were informed that two villas had burned down. 23.54: The four first villas had burned down.

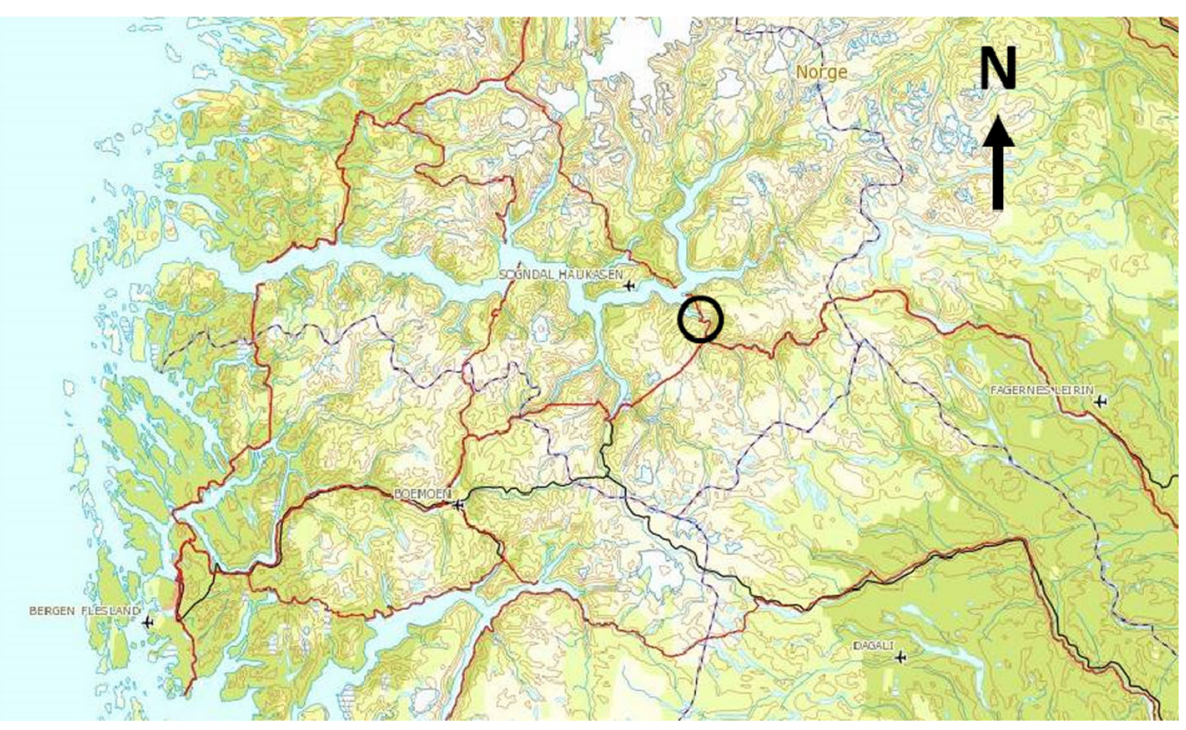

Figure 1. Laerdalsoyri, a sea level village in Sognefiorden, but still in the midst of the main Norwegian mountain region. 


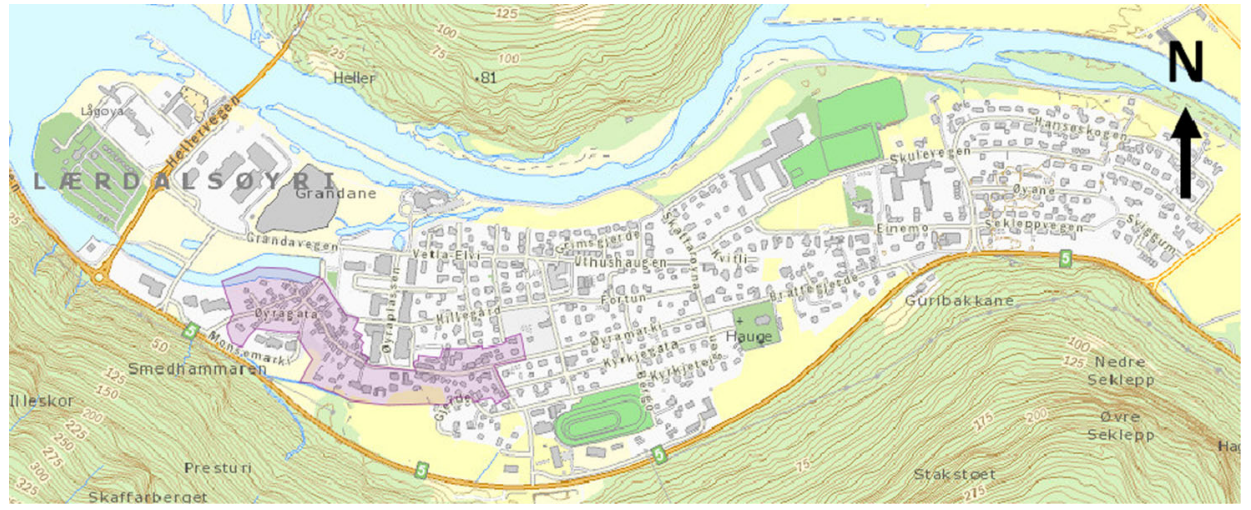

Figure 2. Laerdalsoyri with the $700 \mathrm{~m}$ long Gamle Laerdalsoyri historical site of 161 wooden buildings prior to January 18 th 2014 (marked in lilac color).

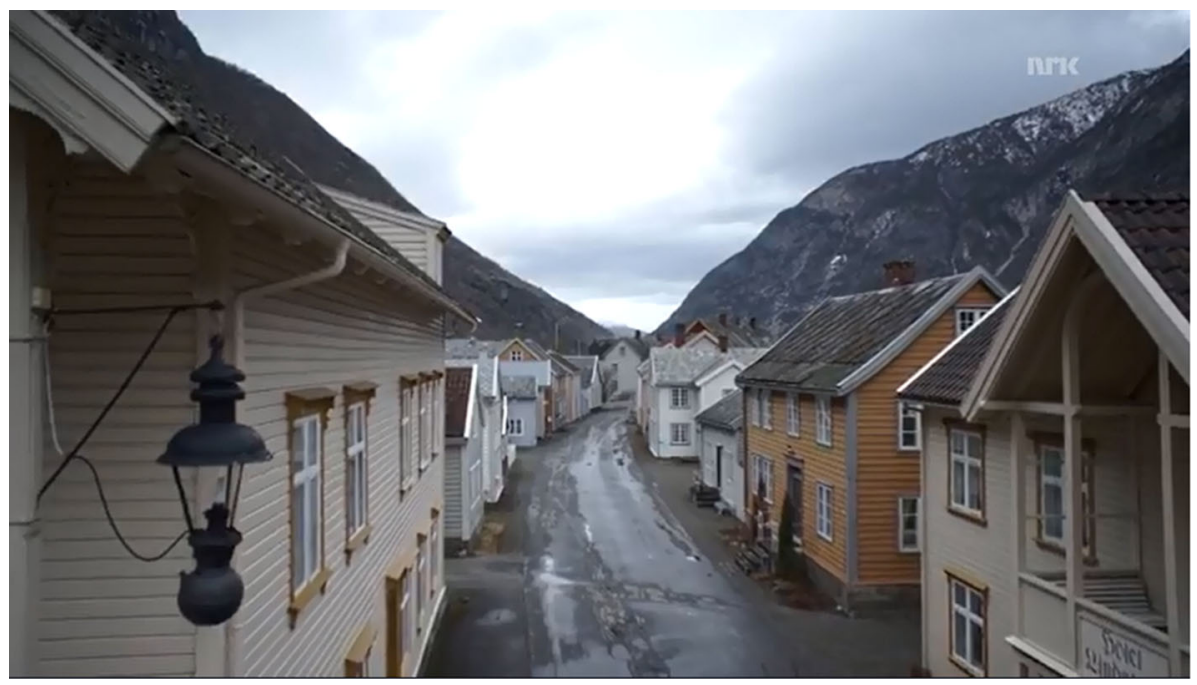

Figure 3. The main street of Gamle Laerdalsoyri historical site, viewing westwards. (Norwegian Broadcasting Corporation (NRK).) Reproduced with permission.

\subsection{Sunday, January 19th}

00.30: There was an electric power outage and village evacuation started. 01.30: At least 7 to 8 buildings were burning. 02.00: The telecommunication central was lost in flames, leaving the area without any telecommunication. At around this time, the fire jumped and involved a private villa $150 \mathrm{~m}$ closer to the historical village. 03.30: One of the heritage buildings was involved in the fire. Shortly afterwards, the listed Synneva Eris house (Figure 4) was ignited. Between 05.00 and 06.00, the wind eased some, and the combined fire brigade forces reported that 


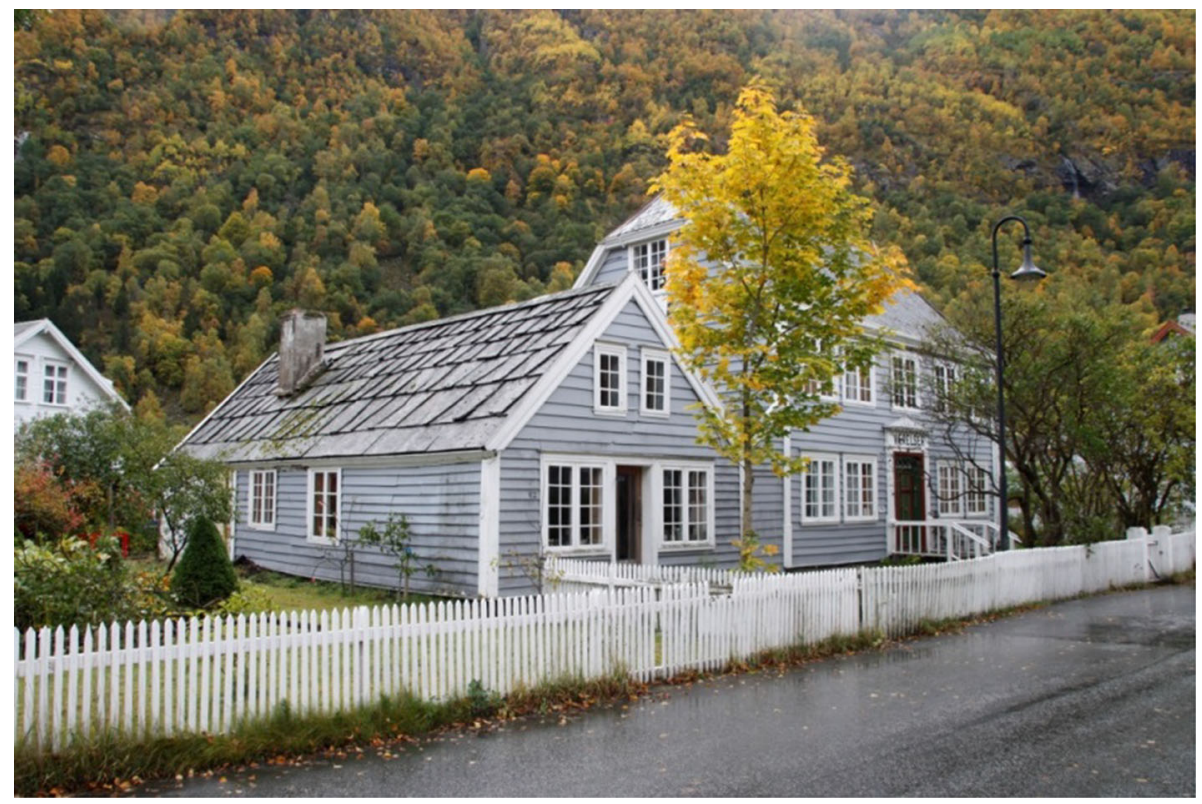

\section{Figure 4. Synneva Eris house from $\sim 1830$ with the small adjacent building. (Photo by Arlen Synnove Bidne.) Reproduced with permis- sion. (The listed building was lost in the blaze January 19th 2014. .).}

the blaze was under control, but still burning. 4 historical buildings were lost in the fire together with 36 modern buildings, among these 17 private villas.

During the fire, assistance from 14 neighbor fire brigade units, as well as units from Bergen, the civil protection forces and the armed forces were mobilized to get the blaze under control (DSB [2]). This was achieved just as the fire had penetrated into the historical village area, as indicated in Figure 5. Without these massive joined forces, together with numerous civilians, farmers applying water with manure wagons, etc. the situation would most likely have developed into an even worse scenario.

During the fire, several smaller wild fires were ignited in the steep valley sides. As these did not possess any threat to people or structures, they were left unattended during the night in order to focus on preventing the main fire from penetrating into the dense Old Lærdalsøyri historical site. The wild fires were extinguished by helicopters during daylight on the second day of the fire as the wind, which previously had been too strong and shifty, had eased sufficiently for helicopter assistance.

\section{Observations by Personnel on the Scene}

In the present work, fire fighters were interviewed in case their observations could reveal information needed to understand the anatomy of the fire. The first fire fighter passed the house of fire origin on his way to the fire station about $90 \mathrm{~s}$ to 


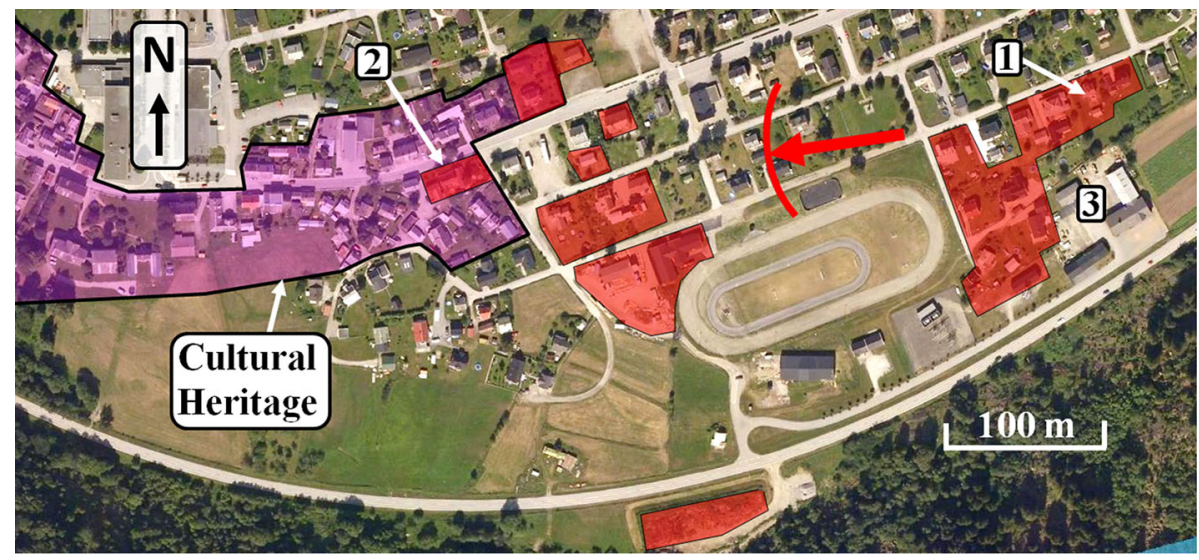

Figure 5. The Laerdalsoyri conflagration area. The most frequent wind direction (storm strength) during the blaze is marked with red arrow. Areas marked in red were destroyed in the fire, involving 4 houses in the culfural heritage area. 1 House of fire origin. 2 Synneva Eris house from 1830. 3 Fire station.

$120 \mathrm{~s}$ after the fire call was made [3]. He observed that the first house had already passed the stage of flashover and burned in a fierce way exceeding what he had previously experienced in fires. The whole house was burning, including the external wooden sidings. When he shortly afterwards arrived with the fire truck to start fighting the fire, the flames emerging from the first house were tilted horizontally by the wind, now touching the neighbor house $15 \mathrm{~m}$ to the west.

The storm strength wind occasionally eased off and suddenly changed $180^{\circ}$ direction followed by full strength in the new direction. The horizontal flames, up to $20 \mathrm{~m}$ to $30 \mathrm{~m}$ length and shifting $\pm 180^{\circ}$, represented a serious threat to the fire fighters. They frequently had to reorganize according to the shifty wind seriously hampering their efforts to control the fire. Such wind shifts are common in Lærdalsøyri in strong easterly gradient winds [4]. This phenomenon is probably caused by large scale turbulence effects from the high mountains, the winding valley and the Sognefjorden fjord systems, all exerting strong influence on any local winds in Lærdalsøyri.

The fires in the neighbor houses to the east and west, which caught fire within a few minutes due to flame impingement from the first house, were also developing rapidly. The fire fighters reported massive production of glowing embers as well as airborne red glowing metal roof plates, representing a deadly threat to the fire fighters. Glowing metal plates hit fire hoses, melted through and cut their water supply $[3,4]$.

The fire fighters reported clean burning (comparably small amounts of soot) and orange flame colors. This flame color and massive embers production were also reported by journalists on the scene and confirmed by numerous photos and videos of the developing conflagration, see Figures 6 and 7. A detailed description 


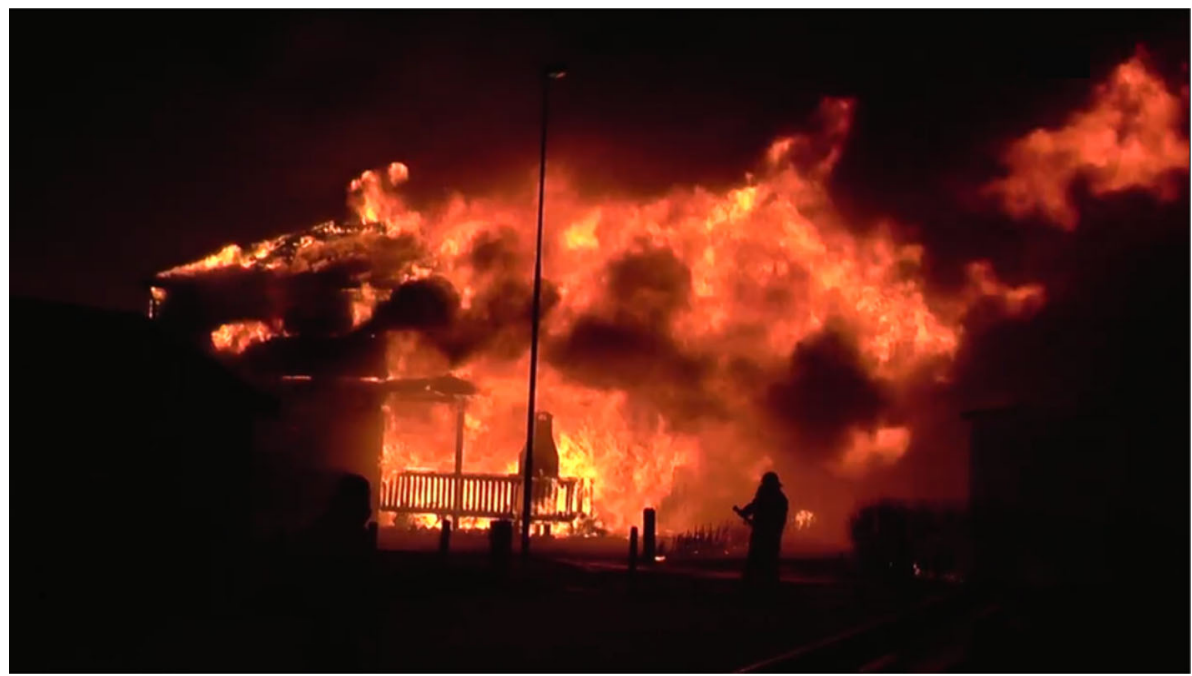

Figure 6. $20 \mathrm{~m}$ to $30 \mathrm{~m}$ long nearly horizontal flames from a villa early in the developing blaze. (Photo by Geir Trulssen). Reproduced with permission.

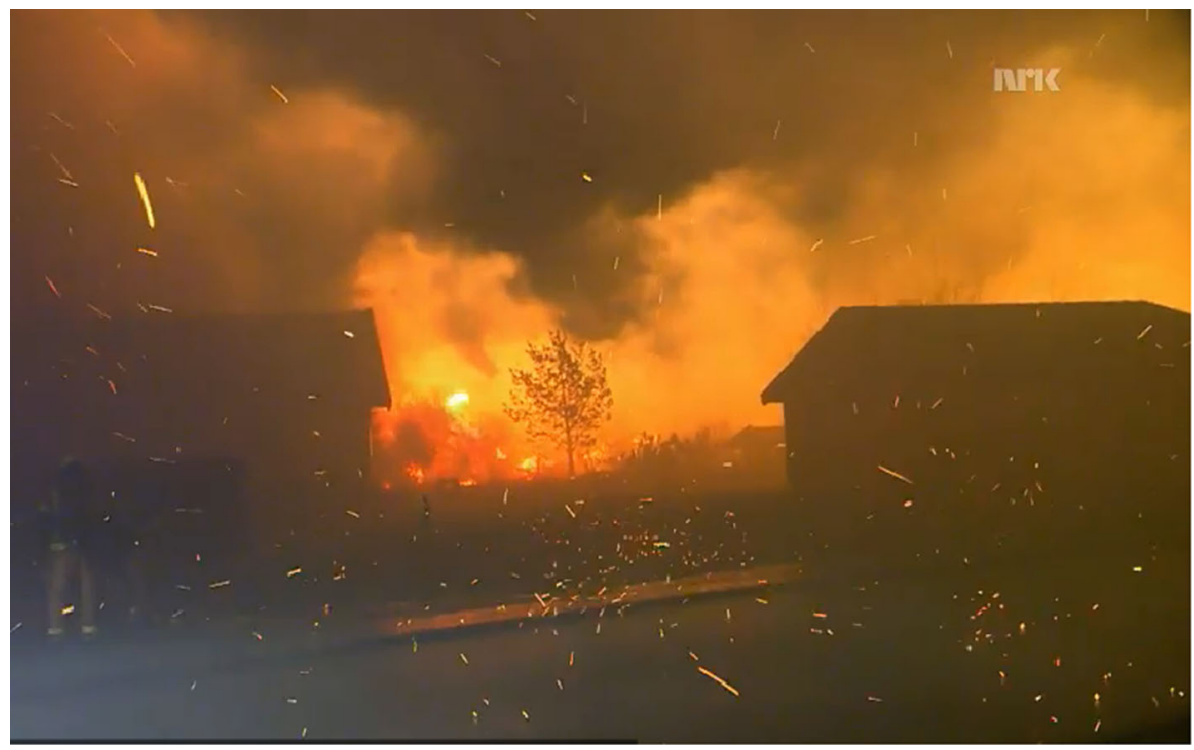

Figure 7. Airborne glowing embers and debris during the fire in Laerdalsoyri. (Photo by Arve Uglum, Norwegian Broadcasting Corporation (NRK)). Reproduced with permission. 
of the fire scenario was presented by the head of the Ardal and Lærdal Fire Brigades at the BFO Spring Seminar 2014 [4].

\section{Analysis of the Fire Scenario}

A fire scenario is best understood by examining the general fire dynamics involved. The fire dynamics needed for the analysis is outlined in Appendix 1. The observed flame color (orange) indicates flame temperatures around $1100^{\circ} \mathrm{C}$ [5]. Such high, and even higher, average room temperatures have also been reported by Lennon and Moore [6] in well ventilated compartment fires with wooden cribs as the fuel source. In strong winds, the observed flame contact to the neighbor house seems inevitable. Optically thick flames (thickness $>2 \mathrm{~m}$ to $3 \mathrm{~m}$ ) of temperatures around $1100^{\circ} \mathrm{C}(1373 \mathrm{~K})$ touching a neighbor house may give a radiant heat exposure approaching $200 \mathrm{~kW} \mathrm{~m}^{-2}$. Unprotected wooden members exposed to such high heat flux levels, including pilot flames, will catch fire within a very short time period $[7,8]$. Using standard values for pine $\left(k=0,14 \mathrm{~W} \mathrm{~m}^{-1} \mathrm{~K}^{-1}\right.$, $\rho=640 \mathrm{~kg} \mathrm{~m}^{-3}$ and $\left.C_{P}=2850 \mathrm{~J} \mathrm{~kg}^{-1} \mathrm{~K}^{-1}\right), \quad T_{i g n}=350^{\circ} \mathrm{C}$ and $\dot{Q}_{E}^{\prime \prime}=200$ $\mathrm{kW} \mathrm{m}^{-2}$, the simplified model for time to ignition, Eq. 15 , gives $t_{\text {ign }} \approx 1 \mathrm{~s}$. In reality it takes more time than this as weather protection paint shields the wood for a short time period, etc. but still, the exposed wood will ignite quickly. When ignited, and if the external flames are still in contact, the burning rate will, according to Eq. 11, be very high. With limited resources, it may also be hard to cool the facades of a neighbor house exposed to heat fluxes of this level as the water applied may not wet the surface properly due to the steam pillow effect [9]. Clean burning and orange flames are also indications of low humidity levels in the wooden fuel.

High fuel moisture content (FMC) will in general limit the fire development in several ways. The heat of combustion $\left(\Delta H_{c}\right)$ will decrease as a function of passive water mass (Eq. 9). The combustion efficiency $(\chi)$ will also be lower. This would give less heat flux from the flame to the fuel surface $\left(\dot{Q}_{F}^{\prime \prime}\right)$ and less external heat flux $\left(\dot{Q}_{E}^{\prime \prime}\right)$ to any potential new fuel (Eqs. 11, 15). High FMC gives increased thermal conductivity and thereby increased internal heat losses $\left(\dot{Q}_{L}^{\prime \prime}\right)$. It also results in increased latent heat of vaporization/pyrolysis $\left(L_{V}\right)$. Evaporated water dilutes the oxygen levels and gives increased heat capacity in the gas phase. For wooden members of high humidity content, all these parameters add up to give low Heat Release Rate (HRR) and slow spread of fire [10]. Slow fire development gives the sap time to expand and evacuate, giving less explosive sap boiling and less ember formation. On the contrary, however, the drier the wood is, the worse all these parameters are with regard to fire development and fire severity.

Pirsko and Fons [11] showed that the frequency of urban building fires was correlated with relative air humidity in the summer and dew point temperature in the winter for the selected areas they studied. Though building materials and construction methods have changed since then, and the correlation may be somewhat weaker today, the findings from 1956 are probably still valid [12]. 
In October 2007, the Trails community (San Diego, CA) was subjected to the severe Witch and Guejito wild fires destroying 74 residences [13]. In the Witch and Guejito fires it took about $2 \mathrm{~h}$ from ignition to complete burn down of the Trails community private homes. According to the Lærdalsøyri police logs, the first four houses in the Lærdalsøyri fire burned down within 23:54, i.e. within $1 \mathrm{~h}$ after the fire in the first house was reported and about $52 \mathrm{~min}$ after it was clear that house number two was ignited. The US and Norwegian building codes differ and the ignition may have taken place in different locations of the structures. The subjective evaluation of when a structure has burned down may also vary. Still, the fast burning of the first four (two floor) villas in Lærdalsøyri indicates that the wooden materials involved were very combustible.

In Lærdalsøyri, the vigorously burning villas ignited numerous smaller wild fires in the surrounding steep snow free mountain slopes by glowing ember and firebrands. In Wildland-Urban Interface (WUI) fires, the wild fires usually ignite the structures. This situation in Lærdalsøyri indicates that the structural wood products were drier than the outdoor threes, shrubs, etc. Since Lærdal is generally known for dry climate, the FMC issue therefore required further investigation.

\section{Air Humidity and Fuel Moisture Content (FMC)}

\subsection{Weather Conditions Prior to the Conflagration}

The daily average temperature and precipitation prior to the fire are shown in Figures 8 and 9, respectively (data from the Norwegian Meteorological Institute, eklima.no database). In the 40 days period prior to January 18 th, the accumulated precipitation was $13.4 \mathrm{~mm}$. The normal for this 40 days period is close to $60 \mathrm{~mm}$, i.e. the precipitation prior to the fire was significantly less than normal. Other factors may also exert influence on the dryness of an area. As an example, the relative humidity at costal Flesland airport (Bergen) in the actual period is shown in Figure 10. It turns out that winds from the east give very low relative humidity at that airport. At Flesland, in the bottom left corner of Figure 1, winds from the

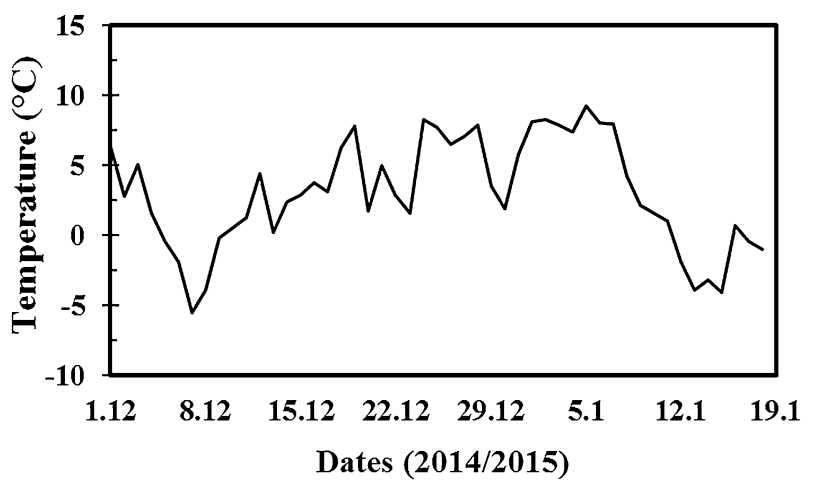

Figure 8. Daily average temperatures (Laerdalsoyri meteorological station) prior to the fire. 


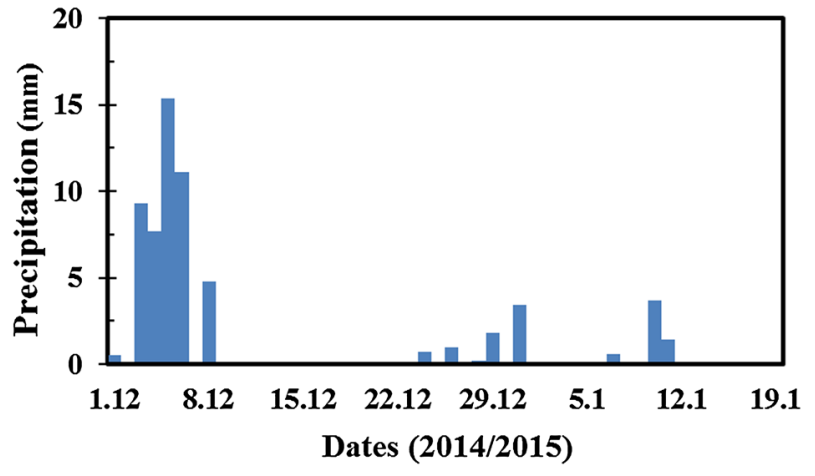

Figure 9. Precipitation (Laerdalsoyri meteorological station) prior to the fire.

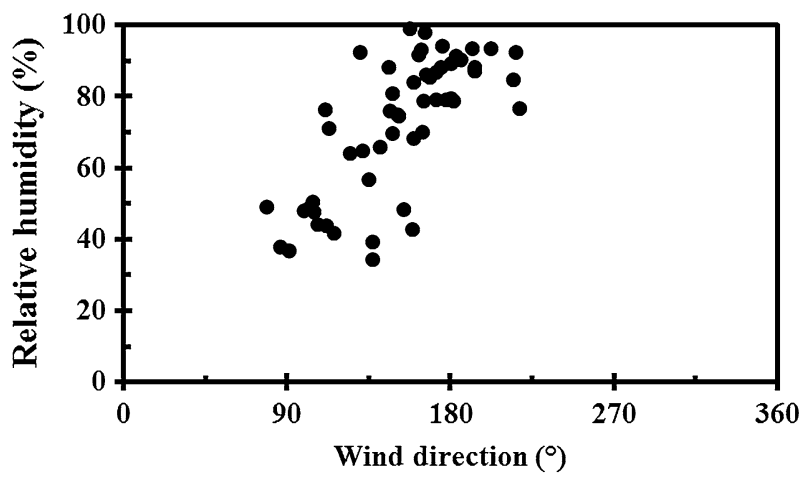

Figure 10. December 9th to January 30th average daily relative humidity at Flesland meteorological station (Bergen) as a function of wind direction.

east comes from high mountain areas while wind from the other directions comes from fjord districts or open sea.

Lærdalsøyri is, as seen on Figure 1, surrounded by mountains. Only wind from due west $\left(270^{\circ}\right)$ can get into Lærdalsøyri without passing over major mountain areas. According to Figure 10, there were no (whole) days of average wind from west during the last 40 days prior to the fire. This indicates that virtually all wind had passed over major mountain areas before entering the Lærdal valley.

\subsection{Relative Humidity ( $\mathrm{RH}$ ) and Wood Equilibrium Moisture Content (EMC)}

The wind that blew into Lærdal during the 40 day period prior to the fire had passed over mountain plains of $+1200 \mathrm{~m}$ elevations, or mountains and glaciers in the range of $1500 \mathrm{~m}$ to $1900 \mathrm{~m}$ elevation, with peaks well over $2200 \mathrm{~m}$. The air entering Lærdal therefore experienced an average elevation change of about 
$1300 \mathrm{~m}$. The typical adiabatic compression lapse rate (i.e. temperature change) is $10^{\circ} \mathrm{C}$ per $1000 \mathrm{~m}$ [14]. This means that any air entering Lærdalsøyri typically experienced $13^{\circ} \mathrm{C}$ temperature increase. The phenomenon of adiabatic heating is well known in California as the Santa Ana winds may result in major wild fires, usually during the period of October through May, such as the previously mentioned Witch and Guejito fires [13]. Adiabatical heating has also been used to explain the conditions leading to the extreme wildfires in Greece and Italy during July and August 2007 [15]. This phenomenon is, however, usually not considered during winter time in cold climates, as pointed out in a winter time wild fire study by Sauvagnargues-Lesage et al. [16]. It does, however, require some attention in the Lærdal valley.

The meteorological station at Finsevatn (1224 m elevation), $40 \mathrm{~km}$ south of Lærdalsøyri, had an average of $86 \%$ relative humidity $(\mathrm{RH})$ in the period December 8th to January 18th. This may be assumed representative also for the mountain areas close to Lærdalsøyri. In order to study the adiabatic compressive drying, we may then assume that the mountain air (at $1300 \mathrm{~m}$ elevation) originally had $86 \% \mathrm{RH}$ and temperature $-10^{\circ} \mathrm{C}$. by:

The pressure as a function of elevation, $h(\mathrm{~m})$, above sea level is generally given

$$
P=P_{0}\left(1-2.2577 \cdot 10^{-5} h\right)^{5.25588}(\mathrm{~Pa})
$$

Given $P_{0}=101325 \mathrm{~Pa}$ at sea level, the pressure at $1300 \mathrm{~m}$ elevation, $P_{1300}$, is $86640 \mathrm{~Pa}$. The $13^{\circ} \mathrm{C}$ heating from $-10^{\circ} \mathrm{C}$ to $3^{\circ} \mathrm{C}$ gives an expansion in accordance to the ideal gas law:

$$
P V=n R T(\mathbf{J})
$$

where $V\left(\mathrm{~m}^{3}\right)$ is the volume, $n(\mathrm{~mol})$ is the number of moles and $R$ is the molar gas constant $\left(8.314 \mathrm{~J} \mathrm{~K}^{-1} \mathrm{~mol}^{-1}\right)$. The saturation water vapor pressure may be calculated by [17]:

$$
P_{s a t}=610.78 \cdot e^{\left(\frac{17.2694 \cdot T_{c}}{T_{c}+238.3}\right)}(\mathrm{Pa})
$$

where $T_{c}$ is the temperature $\left({ }^{\circ} \mathrm{C}\right)$. The water vapor concentration may be calculated by:

$$
C_{s a t}=\frac{P_{s a t} \cdot M_{w}}{R \cdot T}\left(\mathrm{~kg} \mathrm{~m}^{-3}\right)
$$

where $M_{w}$ is the molecular mass of water $\left(0.01802 \mathrm{~kg} \mathrm{~mol}^{-1}\right)$. The relative humidity $(\mathrm{RH})$ is an expression for the actual concentration of humidity in the air to the saturation concentration, $C_{\text {sat }}$. 


\subsection{Outdoor Wood EMC}

According to Eqs. 3 and 4, the saturation concentration of water in $-10^{\circ} \mathrm{C}$ mountain air is $0.00238 \mathrm{~kg} \mathrm{~m}^{-3}$. Given $86 \% \mathrm{RH}$, this mountain air contained 0.00204 $\mathrm{kg} \mathrm{m}^{-3}$ water vapor. When this air was forced down to sea level (Lærdalsøyri), it was compressed by a factor $P_{1300} / P_{0}$ due to the pressure change and expanded a factor $(273+3) /(273-10)$ due to the adiabatic temperature increase. The water vapor concentration at sea level and $+3^{\circ} \mathrm{C}$ then became $0.00228 \mathrm{~kg} \mathrm{~m}^{-3}$. Compared to a saturation concentration at $+3^{\circ} \mathrm{C}$ of $0.00600 \mathrm{~kg} \mathrm{~m}^{-3}$, outdoor wood (hedges, threes, villa cladding, etc.) in Lærdalsøyri experienced 38\% RH. This air then started drying outdoor wooden potential fuel towards the new and drier Equilibrium Moisture Content (EMC), which may be calculated by Simpson [18]:

$$
E M C=\frac{1800}{W}\left\{\frac{K h}{1-K h}+\frac{K_{1} K h+2 K_{1} K_{2} K^{2} h^{2}}{1+K_{1} K h+K_{1} K_{2} K^{2} h^{2}}\right\}(\%)
$$

where

$$
\begin{aligned}
& W=349+1.29 T+0.0135 T_{c}^{2} \\
& K=0.805+0.000736 T_{c}-0.00000273 T_{c}^{2} \\
& K_{1}=6.27-0.00938 T_{c}-0.000303 T_{c}^{2} \\
& K_{2}=1.91+0.0407 T_{c}-0.000293 T_{c}^{2}
\end{aligned}
$$

and $T_{c}\left({ }^{\circ} \mathrm{C}\right)$ is the temperature and $h$ is the relative humidity fraction of water in the air $(\% / 100)$. The air at $3{ }^{\circ} \mathrm{C}$ and $38 \%$ RH has, according to Eq. 5, an EMC of only $7.6 \%$.

\subsection{Wood EMC Inside Inhabited Buildings}

Inside inhabited buildings, the air is heated to a room temperature of about $22^{\circ} \mathrm{C}$ giving a further expansion and water vapor concentration depletion to 0.00213 $\mathrm{kg} \mathrm{m}^{-3}$. Compared to the $22^{\circ} \mathrm{C}$ saturation concentration of $0.01956 \mathrm{~kg} \mathrm{~m}^{-3}$, this corresponds to only $11 \% \mathrm{RH}$ inside these buildings. Due to activities like cooking, persons breathing and sweating, pot plants, etc. a slightly higher relative humidity is more likely. The windy weather during December and January did, however, approximately double the normal air change rate thereby preventing any significant accumulation of humidity from these internal sources. Inside inhabited buildings, the relative air humidity prior to the fire was probably below $20 \%$. Wood panels exposed to air at $22^{\circ} \mathrm{C}$ and $20 \% \mathrm{RH}$ has, according to Eq. 5, a corresponding EMC of $4.5 \%$. This is less than half the EMC at standardized testing (preconditioning to $50 \% \mathrm{RH}$ which corresponds to an EMC-value of 9.3\%). 
When dried to $4.5 \% \mathrm{FMC}$, wood products ignite easier [12] and burn at higher rates compared to the standard test conditions. According to Mindykowski et al. [19], the ignition time for spruce of $4.5 \%$ FMC is about 0.74 times the ignition time of spruce of $9.3 \%$ FMC.

\subsection{Drying Time for Wood Products}

The drying process of wood products may be described by Fick's law:

$$
\frac{\partial C}{\partial t}=D_{W} \cdot \nabla^{2} C\left(\mathrm{~K} \mathrm{~s}^{-1}\right)
$$

where $C\left(\mathrm{~kg} \mathrm{~m}^{-3}\right)$ is the water concentration and $D_{W}\left(\mathrm{~m}^{2} \mathrm{~s}^{-1}\right)$ is the diffusion coefficient of water in wood. The drying time is proportional to the inverse of the thickness squared, i.e. thin objects dry comparably faster (similar to the depth of heating, Eq. 14). Thin wooden panels may dry from both sides, or from one side only due to paint, etc. thereby slowing the drying process. In general, wooden buildings are well ventilated to prevent rot formation and wood deterioration. In windy weather painted internal wall, ceiling and floor panels therefore dry well also through their shielded (unpainted) surfaces in addition to some drying through protective paint and lacquer layers [12].

If a wood panel is suddenly exposed to, and kept exposed to, a constant drier climate at one surface, the internal drying process may be described equivalently to a heat transfer situation where the surface temperature is suddenly reduced and thereafter kept constant. The drying of such a wood panel of thickness $l(\mathrm{~m})$, from time zero to time $t_{D}(\mathrm{~s})$, may therefore be expressed by [20]:

$$
\gamma=1-\frac{4}{\pi} \sum_{n=0}^{\infty}\left[\frac{(-1)^{n}}{2 n+1} \exp \left(-\frac{(2 n+1)^{2} \pi^{2} F o}{4}\right) \cos \left(\frac{(2 n+1) \pi \xi}{2}\right)\right]
$$

where $\gamma$ is the dimensionless change in humidity level within the material and $\xi$ is the dimensionless depth into the panel, i.e. $\xi=x / l$. The Fourier number is given by:

$$
F o=\frac{D_{W} \cdot t_{D}}{l^{2}}
$$

A plot of Eq. 7 for different Fo is shown in Figure 11, where $\gamma=1$ represents the EMC at the previous humid air condition and $\gamma=0$ represents the EMC for the new drier air condition. Typical diffusion coefficients of water in wood are in the range 1 to $5 \times 10^{-10} \mathrm{~m}^{2} \mathrm{~s}^{-1}$ [21]. Assuming now that a $10 \mathrm{~mm}$ thick wooden panel is exposed to the drier climate on one side during a 40 days period, even the lowest of these diffusion coefficients gives $F o>1.8$. According to Figure 11, this indicates that wood panels and other thin wooden objects exposed to the dry air reached their corresponding low EMC values well within January 18th. Thin branches on garden trees, hedges, house sidings, etc. were therefore very dry. 


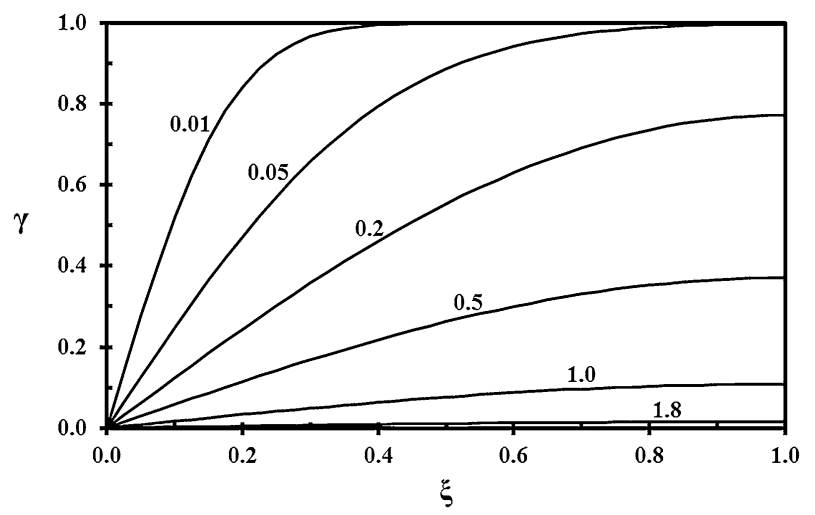

Figure 11. Humidity concentration in wood panels exposed to dry air, i.e. Eq. $7(\xi=x / I)$, with Fourier numbers marked on the curves.

Inside inhabited houses, wood panels and other thin cellulosic objects, such as furniture, were indeed very dry prior to the outbreak of the fire.

The author lives in a 30 years old wooden house in Western Norway, i.e. similar climate and humidity levels as Flesland (Figure 10). It was exceptionally dry and windy in January 2014. In the middle of the month, the solid oak lacquered panels in the sitting room floor for the first time ever detached leaving $1 \mathrm{~mm}$ to $2 \mathrm{~mm}$ gaps between several of the individual panels. The oak panels dried out either through the colorless protective lacquer or through the shielded surface through the rock wool insulation between the ground floor and the first floor. The author then realized that the humidity levels were very low inside the house and warned wife and children about an exceptional fire risk. A neighbor recorded $18 \%$ RH inside their wooden house. Still, probably only the few driest days along the coast were comparable to the situation in Lærdalsøyri.

The low humidity during winter time is generally poorly understood with respect to wild fires [16]. The even lower FMC-values within inhabited houses in cold climates do not seem to get focus as an increased fire risk factor. However, in Lærdalsøyri it certainly was an important reason for the fire fighters having lost control over the fire in the first house(s) even before they arrived at the fire scene. Then, the low FMC, together with the storm strength shifty winds, played an important role in fast ignition, vigorous burning and massive glowing ember formation during the conflagration.

\section{Recommendations}

If the low FMC prior to the fire in Lærdalsøyri had been known and understood, the local fire brigade could have been mentally prepared for the fact that any fire in the strong wind would likely develop into a conflagration. Then they could have prepared accordingly. Meteorological recordings of temperatures and relative 
humidity, and the integral of these values over time combined with EMC and FMC calculations outside as well as inside inhabited buildings, may in the future be worthwhile for assessing the risk of such extreme fires. Local adjustments considering phenomena like adiabatic heating, etc. may then be incorporated in the models. In combination with precise weather forecasts, any increased risk of future severe fires may then be predicted several days in advance. This may be sufficient for mobilizing measures to reduce the probability of a fire outbreak as well as measures mitigating the escalation of a potential fire. The methodology presented, which was used to show that the internal wood products in inhabited houses had reached very low FMC prior to the fire, may be a first approach.

When developing models for predicting FMC inside inhabited buildings, it may be worthwhile to consider wild fire models as an approach. One should, however, keep in mind that even minor changes in wild land fuel may results in poor wild fire risk prediction. As an example, the Canadian Forest Fire Weather Index System works very well for the fuels and situations it is designed for. When using it to predict heathland fire risk [22, 23], it did not predict the humidity levels in the elevated dead (lower canopy) fuel. This fuel has a significant bearing on the fire spread, through an FMC threshold value [24]. It therefore dominates the fire spread properties for the currently dominating +50 years old heather in the UK, as well as in Norway. It is evident that care must be taken when using such models outside the fuel type and climate zones they are designed for. On the other hand, the characteristics of wooden family homes vary less between countries and climate zones than vegetation does. The author is of the opinion that, based on local meteorological observations and the necessity for heating in different climate zones, it may be possible to develop a generic model for internal wooden structure FMC fire risk. It is recommended that such work is undertaken.

Assuming now that the FMC outside, as well as inside inhabited structures, are modeled satisfactorily, it is recommended that this knowledge combined with strong wind weather forecasts result in warnings both to the fire brigades and to the public. Existing summer wild fire warning procedures may prove adequate for winter time fire risk warnings. If the public is warned about extreme fire risks, their fire safety awareness may prevent ignition. Reducing the probability of a start fire should be priority number one. Home owner associations may be engaged and advised to seek web information from countries more likely hit by wild fires. They may be warned that all combustibles in the area, including the structures, may be a threat to the other structures just like vegetation threatens structures in wild fires. In rural areas without permanently manned fire stations, it is recommended to consider personnel on duty in the fire station during predicted high risk situations (when low FMC and strong wind coincide) in order to save valuable response time. In permanently manned fire stations it is recommended to call extra personnel for duty. As ignition may be closely related to climate zone, time of the year, as well as cultural activities (using candle lights, saunas, etc.), and fire spread may be related to area building codes, each case must be evaluated separately by the local fire authorities.

It is general knowledge that dry wood burns well and that strong wind may increase the fire severity and spread the fire fast. Knowing this may, however, not 
be sufficient to understand the combined risk peak. It is therefore recommended that basic research regarding the role of FMC in building fires is undertaken. Pedagogic material illustrating the findings would be beneficial, i.e. such as the NIST Christmas tree and flashover video (http://www.nist.gov/fire/upload/NS_multi. wmv).

To evaluate any measures to stop the developing conflagration was outside the scope of the present work. It should, however, be mentioned that due to night temperature just below zero $\left(-1^{\circ} \mathrm{C}\right.$ to $\left.-2^{\circ} \mathrm{C}\right)$ during the fire, applying water that froze a crust ("icing") on structures downwind probably became an important measure limiting the fire spread. The icecap at roofs and facades left glowing particles less chance to ignite the iced structures. Mobilizing an airport fire truck from Sogndal airport, Haukåsen, with capability of covering numerous structures with heavy foam was a great measure preventing ignition of additional structures. Measures such as these are highly recommended to be included in future contingency plans.

\section{Conclusion}

The Lærdal valley is generally a dry area. Additionally, there was much less precipitation than normal prior to the Lærdalsøyri conflagration January 18th 2014. It is shown that air from surrounding mountains blowing into the valley prior to the fire was adiabatically heated to low levels of relative humidity. It is demonstrated that wooden panels inside inhabited houses had dried to their EMC value of $4.5 \%$. This resulted in severe fire development. Strong shifting winds spread the fire to neighboring structures and over long distances $(200 \mathrm{~m})$. A central finding is that the low FMC inside wooden structures can be predicted as an increased fire risk based on water diffusion in wood.

Without massive fire fighter resources mobilized from elsewhere, including farmers, civilians and an airport fire truck, the outcome would probably have been far worse. Recording, understanding and recognizing parameters indicating a growing fire risk, such as extremely low wood moisture content, is essential for determining proper proactive and reactive mitigating measures. The methodology presented, which was used to show that the internal wood products in inhabited houses had reached low FMC, may be used as a first approach to evaluating cold climate fire risk.

\section{Acknowledgments}

The author is grateful for the valuable information from the locals in Lærdalsøyri. Thanks to Gaute Johnsgård for checking and correcting details regarding the fire brigade and police department $\log$ in the manuscript. Advice and suggestions from the reviewers and the editors are very much appreciated. 


\section{Open Access}

This article is distributed under the terms of the Creative Commons Attribution 4.0 International License (http://creativecommons.org/licenses/by/4.0/), which permits unrestricted use, distribution, and reproduction in any medium, provided you give appropriate credit to the original author(s) and the source, provide a link to the Creative Commons license, and indicate if changes were made.

\section{Appendix 1}

\section{Heat Release Rate (HRR) in fires}

In principle, the single most important parameter that characterizes fire behavior is the heat release rate (HRR) [25]. The HRR may be expressed by:

$$
\dot{Q}_{c}=A_{f} \cdot \dot{m}_{f}^{\prime \prime} \cdot \chi \cdot \Delta H_{c}(\mathrm{~W})
$$

where $A_{f}\left(\mathrm{~m}^{2}\right)$ is the surface area of the fuel, $\dot{m}_{f}^{\prime \prime}\left(\mathrm{kg} \mathrm{m}^{-2} \mathrm{~s}^{-1}\right)$ is the mass flux from the fuel surface, $\chi$ is the combustion efficiency $(\leq 1)$ and $\Delta H_{c}\left(\mathrm{~J} \mathrm{~kg}^{-1}\right)$ is the heat of combustion of the involved fuel. With only a few exceptions, like solid phase oxidation of char coal, the combustion process takes place in the gas phase (flame) where the volatiles (pyrolysis products) from the involved fuel react with entrained oxygen. The heat balance governing the production of volatiles may be expressed by net heat fluxes to the surface and heat consumed for wood pyrolysis and water evaporation:

$$
\dot{Q}_{F}^{\prime \prime}+\dot{Q}_{E}^{\prime \prime}-\dot{Q}_{L}^{\prime \prime}=\dot{m}_{f}^{\prime \prime} \cdot L_{V}\left(\mathrm{~W} \mathrm{~m}^{-2}\right)
$$

where $\dot{Q}_{F}^{\prime \prime}\left(\mathrm{W} \mathrm{m}^{-2}\right)$ is the heat flux supplied by the flame, $\dot{Q}_{E}^{\prime \prime}\left(\mathrm{W} \mathrm{m}^{-2}\right)$ is the heat flux from any external heat source (such as distant flames, hot smoke layers or hot objects), $\dot{Q}_{L}^{\prime \prime}\left(\mathrm{W} \mathrm{m}{ }^{-2}\right)$ is the heat losses from the surface and $L_{V}\left(\mathrm{~J} \mathrm{~kg}^{-1}\right)$ is the latent heat of vaporization and pyrolysis. Rewriting Eq. 10 gives:

$$
\dot{m}_{f}^{\prime \prime}=\frac{\dot{Q}_{F}^{\prime \prime}+\dot{Q}_{E}^{\prime \prime}-\dot{Q}_{L}^{\prime \prime}}{L_{V}}\left(\mathrm{~kg} \mathrm{~m}^{-2} \mathrm{~s}^{-1}\right)
$$

In compartment fires, as the smoke layer temperature increases, the heat flux from the smoke layer (proportional to the smoke layer temperature to the 4 th power) increases dramatically. At smoke layer temperatures around $550^{\circ} \mathrm{C}$ to $600^{\circ} \mathrm{C}$, the fire generally passes through a stage of sudden increase in fire severity, i.e. flashover. Cooling the smoke layer to prevent flashover may therefore be an efficient way to limit the fire development [26]. Post flashover, all combustible surfaces are generally involved in the fire and the mass flow of fuel normally exceeds the amount being combusted by the air flow into the compartment. The excess fuel 
then burns as flames out of the ventilation openings giving potential for external fire spread.

\section{Spread of Flame in Solid Fuel Fires}

Assuming there is no heat production or heat consumption (like evaporating humidity, etc.) in a solid fuel, the heat equation is expressed by:

$$
\frac{\partial T}{\partial t}=a \cdot \nabla^{2} T\left(\mathrm{~K} \mathrm{~s}^{-1}\right)
$$

where $t(\mathrm{~s})$ is the time and $a\left(\mathrm{~m}^{2} \mathrm{~s}^{-1}\right)$ is the thermal diffusivity given by:

$$
a=k /\left(\rho \cdot C_{P}\right)\left(\mathrm{m}^{2} \mathrm{~s}^{-1}\right)
$$

where $\rho\left(\mathrm{kg} \mathrm{m}^{-3}\right)$ is the density and $C_{P}\left(\mathrm{~J} \mathrm{~kg}^{-1} \mathrm{~K}^{-1}\right)$ is the specific heat capacity. When a fire is heating solid objects there will initially be large heat losses into the solid due to the steep temperature gradients just inside the surface over the "depth of heating" expressed by:

$$
\delta=\sqrt{a t}(\mathrm{~m})
$$

Assuming that wood ignites at a certain surface temperature, $T_{i g n}$, usually in the range $325^{\circ} \mathrm{C}$ to $350^{\circ} \mathrm{C}$, solving Eq. 12 for a constant heat flux to a semi-infinite solid and eliminating external heat losses, the time to ignition may be estimated by [20]:

$$
t_{i g n}=\frac{\pi}{4} k \rho C_{p}\left[\left(T_{i g n}-T_{o}\right) / \dot{Q}_{E}^{\prime \prime}\right]^{2}(\mathrm{~s})
$$

After ignition, the mass flux (Eq. 11) increases due to heat flux from flames, hot smoke and other hot fuel surfaces as well as less heat losses due to the increased "depth of heating".

\section{References}

1. Steen-Hansen A, Bøe GA, Hox K, Mikalsen RF, Stensaas JP, Storesund K (2015) Evaluation of fire spread in the large Lærdal fire, January 2014. In: 14th international fire and materials conference and exhibition, 2-4 February 2015, p 1014-1024

2. DSB Report (2014) Brannene I Lærdal, Flatanger op på Frøya vinteren 2014, Lærepunkter og anbefalinger/The Fires in Lærdal, Flatanger and Frøya the Winter 2014, Learning Points and Recommendations. Norwegian Directorate for Civil Protection, Dec. 2014, 55 pp, ISBN: 978-82-7768-342-3 (In Norwegian)

3. Figenschau A (2014) Fire fighter interviewed in the present work

4. Johnsgård G (2014) What can we learn from Lærdal, Brannfaglig Fellesorganisasjon (BFO), Spring Seminar 3-4 April 2014, Qality Airport Hotel, Gardermoen

5. Drysdale D (2011) An introduction to fire dynamics, 3rd edn. Wiley, Chichester 
6. Lennon T, Moore D (2003) The natural fire safety concept-full-scale tests at Cardington. Fire Saf J 38:623-643. doi:10.1016/S0379-7112(03)00028-6

7. Simms DL (1963) On the pilot ignition of wood by radiation. Combust Flame 7:253261

8. Shi L, Chew MYL (2013) Experimental study of woods under external heat flux by autoignition. Ignition time and mass loss rate. J Thermal Anal Calorim 111(2):13991407. doi:10.1007/s10973-012-2489-x

9. Leidenfrost JG (1966) On the fixation of water in diverse fire. Int J Heat Mass Transfer 9:1153-1166

10. McAllister S (2013) Critical mass flux for flaming ignition of wet wood. Fire Saf J 61:200-206. doi:10.1016/j.flresaf.2013.09.002

11. Pirsko AR, Fons WL (1956) Frequency of urban building fires as related to daily weather conditions, Interim Technical Report AFSWP-866. US Department of Agriculture, Forest Service, Division of Fire Research, Washington, DC

12. Babrauskas V (2003) Ignition handbook. Fire Science Publishers, Issaquah

13. Maranghides A, Mell W (2011) A case study of a community affected by the Witch and Guejito wildland fires. Fire Technol 47(2):379-420. doi:10.1007/s10694-010-0164-y

14. Jacobson MZ (2005) Fundamentals of atmospheric modeling, 2nd edn. Cambridge University Press, New York

15. Amraoui M, Liberato MLR, Calado TJ, DaCamara CC, Coelho LP, Trigo RM (2013) Gouveia CM (2013) "Fire activity over Mediterranean Europe based on information from Meteosat-8". For Ecol Manage 294:62-75. doi:10.1016/j.foreco.2012.08.032

16. Sauvagnargues-Lesage S, Dusserre G, Robert F, Dray G, Pearson DW (2001) Experimental validation in Mediterranean shrub fuels of seven wildland fire rate of spread models. Int J Wildl Fire 10(1):15-22. doi:10.1071/WF01006

17. Tetens O (1930) Uber einige meteorologische Begriffe. Zeitschrift fur Geophysik 6:297

18. Simpson WT (1998) Equilibrium moisture content of wood in outdoor locations in the United States and worldwide. Res. Note FPL-RN-0268. U.S. Department of Agriculture, Forest Service, Forest Products Laboratory, Madison

19. Mindykowski P, Jørgensen M, Svensson S, Jomaas G (2015) Determination of the Moisture Content of Nordic Spruce Wood with an Integral Model. In: Merci B, Boustras G (eds) Proceedings of the 2nd European Symposium on Fire Safety Science, Nicosia, Cyprus, June 16-18, 2015. ISBN: 978-9963-2177-0-0, p 230-233

20. Carslaw HS, Jaeger JC (1959) Conduction of heat in solids, 2nd edn. Oxford Science Publications, Oxford

21. Baronas R, Ivanauskas F, Juodeikienè I, Kajalavičius A (2001) Modelling of moisture movement in wood during outdoor storage. Nonlinear Anal Model Control 6(2):3-14

22. Davies GM, Legg CJ, O'Hara R, MacDonald AJ, Smith AA (2010) Winter desiccation and rapid changes in the live fuel moisture content of Calluna vulgaris. Plant Ecol Divers 3(3):289-299. doi:10.1080/17550874.2010.544335

23. Krivtsov V, Legg C (2011) Modelling soil moisture deficit and moisture content of ground vegetation: progress towards development of a fire weather index system appropriate to the UK. Fire Technol 47(2):539-548. doi:10.1007/s10694-010-0184-7

24. Davies GM, Legg CJ (2011) Fuel moisture thresholds in the flammability of Calluna vulgaris. Fire Technol 47(2):421-436. doi:10.1007/s10694-010-0162-0

25. Babrauskas V, Peacock R (1992) Heat release rate: the single most important variable in fire hazard. Fire Saf J 18:255-272. doi:10.1016/0379-7112(92)90019-9

26. Log T, Cannon Brookes P (1995) Water Mist for fire protection of historic buildings and museums. Mus Manag Curatorship 14(3):283-298. doi:10.1080/09647779509515447 